\title{
AN OPTIMISTIC REVIEW OF THE IMPACT OF NEW \\ PUBLIC MANAGEMENT REFORMS IN CENTRAL AND \\ EASTERN EUROPE
}

\author{
Sorin Dan and Christopher Pollitt \\ Preprint \\ Published in Public Management Review, online first, 2014 \\ (http://www.tandfonline.com/doi/full/10.1080/14719037.2014.908662\#.U1-Oj6LyRol)
}

\author{
Sorin Dan \\ Doctoral researcher \\ Public Governance Institute \\ KU Leuven \\ Leuven, Belgium \\ E-mail: sorin.dan@soc.kuleuven.be \\ Christopher Pollitt \\ Emeritus Professor \\ Public Governance Institute \\ KU Leuven \\ Leuven, Belgium \\ E-mail: christopher.pollitt@ soc.kuleuven.be
}

\begin{abstract}
This article reviews the New Public Management (NPM) literature in Central and Eastern Europe with the aim of assessing whether reforms have 'worked'. Increasingly academics have tended to argue against the suitability of NPM instruments in this region. To understand the impact of this much-debated policy, we first propose a classification of the impacts of NPM geared to the realities of Central and Eastern European states. Then we use this classification to carefully review empirical studies across the region over the past ten years. Unlike much of the recent academic literature, we suggest that NPM can work. NPM policy has not always been successful to the extent expected and promoted, but there is enough evidence to show that some of the central ideas in NPM have led to improvements in public service organization or provision across different organizational settings. An adequate degree of administrative capacity, sustained reform over time and a 'fitting context' are the main
\end{abstract}


factors which can tip the scale for the success of these management instruments. The paper provides a fresh and transparent assessment of a major administrative development in a growing region with implications for other parts of the world that experience similar challenges and opportunities.

\section{Keywords}

New Public Management, impact, public sector reform, Central and Eastern Europe

\section{INTRODUCTION}

This article reviews existing evidence on NPM reforms in Central and Eastern Europe (CEE) over the past ten years with the goal to evaluate their impact across this region. There are three principal reasons why such a review is needed, and can make a contribution to the current fragmented body of research into NPM. First, most of this research has concentrated on strongly NPM (usually Anglophone) countries and, to a lesser extent, on the Western world more generally. New European Union states in Central and Eastern Europe have received much less attention although these states have extensively experimented with NPM ideas and instruments (see for example Bouckaert et al. 2008; Nemec 2010; Nemec and de Vries 2012). Second, not enough is known of the conditions under which NPM instruments may or may not 'work'. Third, increasingly these reforms and instruments have acquired a bad reputation among academics in Central and Eastern Europe. This reflects a larger trend in administrative reform that has increasingly questioned the virtues of NPM. Some commentators have critically evaluated the idea and the existing evidence, while others have dismissed it altogether. We argue that this has created an imbalanced - and unsubstantiated view of the impact of NPM policy. More often than not, NPM instruments have been criticized for what they have failed to deliver while ignoring what they have managed to produce. This paper takes a different approach and argues that a more favorable picture of the impact of NPM is better aligned with the existing empirical evidence than the picture that currently prevails among academics in the region. The paper provides a fresh and critical look at a much-debated administrative development in a changing region with implications for other parts of the world that experience similar problems and opportunities. The article begins with an overview of past work into NPM in CEE and distinguishes between studies that looked at NPM in general and work that focused on specific NPM instruments and reforms. It then discusses the methods and proposes a classification of the impact of NPM. The article then moves on to present and discuss the findings followed by conclusions and discussion.

\section{EVALUATING NPM IN CENTRAL AND EASTERN EUROPE}

This article is not the first to review the impact of NPM in Central and Eastern Europe. Other studies exist (Bouckaert et al. 2008; Bouckaert, Nakrošis and Nemec 2011; Caddy and Vintar 2002; Drechsler 2005; Drechsler 2009; Dunn et al. 2006; Nemec 2010; Nemec and de Vries 2012; Nemec and Kolisnichenko 2006; Peters 2008; Verheijen and Dobrolyubova 2007). In 
this section we look at these other studies and draw conclusions about the current state of NPM scholarship in CEE. According to the degree of generality, there are two main types of work on NPM: work that views NPM in general terms and studies that focus on specific NPM instruments, such as performance-related pay or contracting out. We first discuss general NPM studies and then turn to discuss past work on specific NPM instruments.

\section{General NPM reform}

Nemec (2010) looks at NPM reforms in CEE and argues that there are clear differences across countries in the weight of this policy in the broader public sector reform programs. The author focuses on a number of studies in Estonia, Slovakia and the Czech Republic evaluating practices such as contracting out, benchmarking, decentralization and performance budgeting. It finds that success depends on the type of NPM instrument as well as on "concrete local conditions and the environment" (p. 40). It discusses a number of factors characteristic of the transitional state of the public sector that affect the possible success of NPM as a whole. They include underdeveloped competitive markets (see also Bouckaert et al. 2008; Bouckaert, Nakrošis and Nemec 2011; Nemec and Kolisnichenko 2006), developing democratic institutions and citizen accountability, the quality of the state of law, corruption, territorial fragmentation and lack of sufficient administrative capacity to design, implement, monitor and evaluate policy (see also Peters 2008; Nemec and de Vries 2012). The article concludes that some positive impacts of NPM tools such as benchmarking seem apparent, but it does not discuss these positive effects in detail. Overall, the conclusion is that "NPM tools and mechanisms delivered very mixed results in the CEE region, more negative than positive, mainly not because of their character, but because of their wrong implementation or nonimplementation" (p. 46). These conclusions seem to indicate that there is nothing inherently wrong with NPM tools as long as adequate implementation and suitable local conditions are in place (see also Dunn et al. 2006). A few other reviews have reached similar conclusions (Bouckaert et al. 2008; Bouckaert, Nakrošis and Nemec 2011; Nemec and de Vries 2012). They emphasize that the context in CEE differs from that of Western countries where NPM originated, and that this context proved instrumental. Political and administrative instability is one additional, frequently-mentioned contextual factor that hampers long-term systemic reform - importantly, both NPM or of a different type. Nemec and de Vries (2012) point out that NPM may not have worked in fragile democracies in Eastern Europe and the former Soviet Union because it prioritized efficiency gains and cutbacks in public expenditure whereby what was primarily needed was building democratic institutions and developing civil service systems and administrative capacity. In this case, the authors argue, NPM did not deliver as expected because it was not the right solution in the first place. Similarly, MeyerSahling and Yesilkagit (2011) note that administrative traditions in CEE, unlike those in Western Europe, are characterized by long-term instability, inconsistent ideas, institutions and practices, and dependence on external pressure.

Public management reforms in CEE have often been proposed and implemented in a piecemeal manner (Bouckaert, Nakrošis and Nemec 2011; Randma-Liiv et al. 2011; see also Van Thiel 2011 concerning the approach to agencification in CEE). In their detailed study of 
implementation, Dunn et al. (2006: 20-23) discussed seven conditions that can facilitate or, in some cases, obstruct policy and reform implementation. They underline that these conditions are rarely met in CEE, which can explain why many administrative reforms were poorly implemented or were not implemented at all. They are management and policy design and skills, clarity and specificity of rules and operating routines, core and secondary belief change, anticipatory impact assessment, institutionalization of monitoring and evaluation, and policy communication. The volume shows how implementation is retarded because of one or more of these unmet conditions influencing policy and reform impacts.

There is relatively little discussion of positive findings associated with NPM in the above overviews of the literature. Some examples of positive impacts do exist, but they do not constitute the main focus and are rarely attributed to NPM. For example, reform achievements are found in areas such as financial management, human resource management, organizational changes, IT\&C systems, and performance and quality management (Bouckaert et al. 2008; Bouckaert, Nakrošis and Nemec 2011). It can be argued, first, that with the exception of performance and quality systems, these other instruments are not NPM. Second, these achievements refer to the introduction of new performance and quality systems, and very little to the impact of these systems. Tönnisson (2006) assesses the perception of heads of Estonian local governments and finds empirically that their evaluation of the effects of NPM is overall positive. The paper, however, focuses on why NPM does not work - rather than on what works about NPM. It argues that social desirability bias, theoretical underpinnings of reform, and implementation gap alter these perceptions. However, empirically, NPM was perceived to generally work (Tönnisson, 2006).

Other academics have directly questioned the virtues of NPM in a public sector context. For instance, Drechsler (2005; 2009) and Drechsler and Kattel (2008) argue that NPM has been a failure in CEE and should be renounced virtually entirely. Virtually entirely means that certain NPM instruments may still be used as part of a broader reform program but this program must be strongly rooted in a Neo-Weberian logic if these NPM elements are to be of any good use (Drechsler 2005; Drechsler 2009; for a comparative analysis of NPM and the Neo-Weberian State, see Pollitt and Bouckaert 2011). It is argued that NPM has failed to work not because the right context was not in place or because of lack of implementation capacity, but because the logic of NPM is inherently faulty. Under such a scenario, there seems to be no escape - unless it embraces a Weberian logic and transforms into something else, NPM is doomed to fail.

\section{Specific NPM reforms and instruments}

A second broad type of research into the impact of NPM in CEE concerns specific NPM reforms. These studies rarely concentrate on, evaluate and view NPM as a whole. They discuss tools such as quality improvement schemes, contracting out or performance management and measurement techniques. On a more positive note, Verheijen and Dobrolyubova (2007) evaluate performance management systems in Latvia, Lithuania and the Russian Federation. While performance management is not a panacea and sustained effort is 
needed, the study provides evidence that performance management can lead to positive effects in CEE administrative systems. The authors argue that this finding 'contradicts the widely held notion that performance-based public management systems are not suitable for 'developing' countries' (p. 205). Nonetheless, certain pre-requisites are necessary for this to happen. First, a step-by-step, incremental approach to implementation can overcome barriers to complex change. Second, in low-capacity environments typical of transitional states, it is important to adapt the scope and speed of reform to reflect available capacity on the ground. As the study puts it, certain vulnerabilities remain, and they need to be tackled first before reform is expected to deliver. They include translating overall performance objectives into individual performance targets, creating a results-based culture and developing capacity and human resource systems (p. 214). Despite these areas where continued attention is needed, there is evidence that much has been achieved in particular on strategic, ministry- and agencylevel performance management, which can have "important pay-offs both in improved fiscal management and, in the longer run, service delivery quality" (p. 214). Tõnnisson and Wilson (2007) assess the perception of local government managers in Estonia using the UK's Best Value framework. They found that local governments had pursued a performance-based agenda, but identified possible contradictions between the managers' perceptions and the reality of using performance tools on the ground. The article does not seek to assess the impacts of performance reform, but rather it surveys the extent to which such reform has been implemented and how it is perceived by local managers. Nemec (2007) discusses lessons from decentralization reforms. He argues that decentralization may have both negative and positive impacts depending on country-specific conditions. In a weak democratic system with little respect for the rule of law, high levels of corruption and low implementation capacity, decentralization is likely to give rise to clientelism and rent-seeking behavior. Under such circumstances it is unlikely that the positive expectations of decentralization will be achieved (see also Nemec, Merickova and Vitec 2005 for a review of contracting out and Nemec and Kolisnichenko 2006 for a review of marketization in healthcare). However, this does not mean that decentralization is inherently unproductive (Nemec 2007). Decentralization has been and remains central to administrative reform in the region leading to a need for effective coordination (e.g. Sarapuu 2011). A special issue in the Transylvanian Review of Administrative Sciences (2011) provides an overview of experiences with agencies in Croatia, Estonia, Hungary, Lithuania, Romania and Slovakia, and discusses the specifics of agencification and the public sector context in CEE (see also Nakrošis and Martinaitis 2011 and volume V number 2 Winter 2012/2013 "The Politics of Agency Governance" in the NISPAcee Journal of Public Administration and Policy). These studies point to the following findings: i) there is limited empirical evidence documenting the impact of agency creation in $\mathrm{CEE}$; ii) the approach to agency creation has often been piecemeal rather than systematic; iii) less funding and capacity to develop and implement agency reform were available compared to Western countries (Van Thiel 2011); iv) coordination mechanisms are still developing, which makes further autonomization and agencification problematic leading to fragmentation in those countries which pursued a more aggressive agenda (Randma-Liiv et al. 2011); v) in high-corruption environments granting greater autonomy to agencies and service delivery organizations may lead to rent-seeking and waste. Nevertheless, some cases found improved results (for example the Slovakian case). Overall, although certain problems have been 
observed, some argued that the creation of agencies was "an important step forward in Slovakia and elsewhere in CEE” (Nemec, Mikusova Merickova and Vozarova 2011: 140; see also Pollitt 2004 for a study of agencies in Latvia).

This overview has revealed the following characteristics of the academic literature on NPM in the region. The literature frequently discusses and draws conclusions about the impact of NPM but provides limited systematic evidence. Second, the impacts of NPM reforms are various and depend on a multitude of factors and conditions. This makes generalizations difficult to support with evidence. However, this has not prevented some studies from making sweeping claims. Increasingly, these conclusions have taken a pessimistic turn and claimed that NPM does not work while failing to show what works about NPM. We argue that these reasons call for a transparent and systematic assessment of the existing evidence, a refined classification of the impacts of NPM instruments and reforms and a more balanced understanding of these impacts.

\section{METHODS}

\section{Study identification and selection}

The identification and selection of studies consisted of two steps. The first step involved the creation of a database of studies of NPM reforms in Europe as part of an international comparative project (see Pollitt and Dan 2011; Pollitt and Dan 2013 for more details).

In addition, using the same criteria we reviewed articles in the following main public administration and management journals in the CEE region: Halduskultuur, NISPAcee Journal of Public Administration and Policy, Transylvanian Review of Administrative Sciences and Uprava-Administration. In each case we checked the journal from its first issue up to August 2013. These journals were selected to account for frequently-used academic sources emanating from different countries in Central and Eastern Europe.

\section{Data extraction and synthesis}

An analytical framework (reported in the Appendix) guided the categorization and synthesis of data. We used the classification of the impact of NPM reforms (Figure 1 below), which we propose, and confronted it with a review of the empirical literature. The Appendix shows for each study the specific NPM reform or instrument, country, the organizational setting, methods used and the overall impact of reform. We were interested in what variables or factors the empirical literature uses to explain the impact of NPM instruments, and therefore included an additional column in the Appendix reporting these factors.

\section{Classification of the impact of NPM reforms}

To understand the impact of NPM reforms we propose the following classification. We argue that a framework that explicitly accounts for various explanations better reflects the reality on the ground. The focus of this article is on NPM policies in CEE countries. However, this 
classification may be applicable to countries in other regions as the elements in the taxonomy are not exclusive to Central and Eastern Europe alone.

Figure 1: Classification of the impact of NPM reforms

I. NPM reforms do not work regardless of administrative capacity and type of context

II. NPM reforms do not work mainly because of insufficient administrative capacity

III. NPM reforms do not work mainly because of unfitting context

IV. NPM reforms do not work because of insufficient administrative capacity or unfitting context but reforms can still lead to certain positive effects

V. NPM reforms can have significant positive effects, but they can be hindered by insufficient administrative capacity or unfitting context

VI. NPM reforms work although they can lead to certain unintended consequences and trade-offs

VII. NPM reforms usually or always work

From type I to type VII there is a progression from total failure to complete success. In between there are different possibilities why NPM instruments may or may not prove effective. In some situations, the costs may exceed the benefits while in others the evidence for the benefits may outweigh possible negative consequences. Type I simply means that NPM reforms are inherently unfitted for a Central and Eastern European state and will never produce any positive benefits regardless of administrative capacity or type of context. The argument is essentially that the logic of NPM is itself faulty. Types II and III include explanations why NPM will not work, which we term administrative capacity (for type II) and "unfitting context" (for type III). In these cases the logic may not be faulty, but the concrete circumstances conspire to defeat the reform. We use these terms as follows: administrative capacity includes the skills to develop, implement and evaluate policy as well as human, financial and material resources. We differentiate administrative capacity from context which includes the characteristics of the political and administrative system, the financial and economic condition of the state at a particular time as well as prevailing social and cultural values. Type IV builds on types II and III, but is different in that, although evaluated as unsuccessful, NPM reforms lead to certain improvements in the organization or provision of public services. Type V constitutes a tipping point in our classification. Starting with type V the effects of reforms are evaluated increasingly positively. Instruments may still be hindered by lack of administrative capacity or unfitting context, and include a mixture of success and failure. Type VI includes studies which have found favorable evidence. Type VII is positioned at the end of the spectrum, and includes studies which have found reforms to be a complete success. 


\section{HAS NPM REALLY FAILED?}

The Appendix shows different impacts of NPM reforms and factors influencing these impacts. The picture is nuanced, and the classification proposed has the merit of transparently bringing this picture to light. A first clear observation is that NPM reforms have neither been a complete failure nor a complete success. None of the empirical studies that look at specific reforms could be classified as Type I 'NPM reforms do not work regardless of administrative capacity or type of context' or Type VII 'NPM reforms always or usually work'. Most work would best be classified as partial success (Type V'NPM reforms can have significant positive effects but they can be hindered by insufficient administrative capacity or unfitting context'). One may argue that partial success involves partial failure. A fifth of studies (seven out of 32, classified as type I to type III) have found evidence of partial failure and expressed serious concerns about the suitability of NPM reforms in a developing context. Examples include unfavorable evidence on performance-related pay in Estonia (National Audit Office of Estonia 2002; Randma-Liiv 2005; Nõmm and Randma-Liiv 2012) and Hungary (Linder, 2011), contracting out emergency medical service in Estonia (Lember 2006), and contracting out in local governments in the Czech Republic and Slovakia (Nemec, Merickova and Vitec 2005). Other similar studies include experience with decentralization in Estonia (Järvalt and Randma-Liiv 2010) and Romania (Baba et al. 2007) and general modernization reform with NPM elements in Romania (Șandor and Tripon 2008). There are a number of observations that need to be made about this subset of studies. First, although the bulk of evidence would point to failure, some also find certain positive developments following reform. It may not be what was originally intended, but there is evidence of improvement in other areas of public service organization or provision. For instance, decentralizing human resource management in the Estonian central government created an impetus for positive change, facilitated other major public sector change and afforded the flexibility to implement reform at the organizational level (Järvalt and Randma-Liiv 2010). Second, there seems to be a bias in this broadly negative section of the literature and a focus on what does not work at the expense of what does work. Fuelled by optimistic reform campaigns and promises (which facilitated implementation in the first place) expectations were set very high. When we look at the evidence in this subset of the database, however, we see that it is often ambivalent - with partial success and failure, positive developments in certain areas coupled with deteriorations in other areas. The wine glass may be half empty, but if we are interested in drinking wine, the more significant observation is that it is half full.

\section{NPM reforms can work: the importance of administrative capacity and 'fitting context'}

Many of the empirical studies (18 out of 32) can best be classified as Type V"NPM reforms can have significant positive effects but they can be hindered by insufficient administrative capacity or unfitting context". The idea underlying this category is that there is some evidence pointing to positive impacts, but the evidence is less convincing due to barriers arising from lack of capacity and/or contextual factors hindering reform. Unlike Type VI studies, the 
studies classified as Type V point to a limited success. Examples include Nakrošis (2008) for performance management in central government in Lithuania, Kovač (2008) as well as Kovač and Leskovšek (2009) who evaluated quality improvement schemes in Slovenia. Similarly, Tõnnisson (2004) provides evidence of the impact of quality models in Estonia, Jenei and Gulácsi (2004) in Hungary and Reinholde (2004) in Latvia. Similar arguments have been made in the case of contracting out in Hungary (Jenei et al. 2005; Osborne, Jenei and Fabian 2008) and agencification in Croatia (Musa and Kopric 2011), Lithuania (Nakrošis and Martinaitis 2011) and Slovakia (Nemec, Mikušová Meričková and Vozárová 2011). Similarly these factors were found instrumental in assessing benchmarking in Estonia, Czech Republic and Slovakia (e.g. Nemec, Merickova and Ochrana 2008; Nemec, Merickova and Sumpikova Fantova 2011; Tõnnisson and Wilson 2007). The same is true for general modernization reform with evidence found in the Estonian public sector (Tõnnisson 2006) as well as in Latvia and Lithuania (e.g. World Bank 2006) and Romania (e.g. Profiroiu et al. 2006; Profiroiu et al. 2010). These cut across different countries and organizational settings. Importantly, none of these studies contest the idea of NPM success - as some studies in Types I to IV do. Rather, they argue that reforms would have likely worked under different circumstances. A frequent practical recommendation is to sustain reform over a longer period of time while at the same time building policy development, implementation, and evaluation capacity. A second recommendation is to adapt NPM practices to best fit the national or local context. Failing to take context seriously can be costly (e.g. Baba et al. 2007; Șandor and Tripon 2008). For example, failing to adapt decentralization and deconcentration reform to the Romanian context characterized by duplication of tasks led to administrative bottlenecks (Baba et al. 2007). Similarly, a Romanian public sector characterized by excessive politicization and a complicated legal framework affected implementation (Șandor and Tripon 2008). NPM in other more favorable contexts, as we see in greater detail below, have been evaluated more positively, which shows that reforms could work as long as administrative capacity is adequate and they are developed and implemented in such a way so as to fit the national or local context.

\section{Evidence of positive impact of performance management}

Verheijen and Dobrolyubova (2007) convincingly argue that despite initial skepticism, performance management proved successful in a Central and Eastern European context. They found that an incremental approach to reform facilitated implementation. Adaptation of performance management to existing capacity levels was an additional success factor. Other research on performance management in the region found similar evidence. A survey-based evaluation of civil service change in Lithuania recommended a move towards NPM ideas such as position-based human resource management and performance-related pay (MeyerSahling and Nakrošis 2009). Along similar lines, Nakrošis (2008) argues that despite insufficient resources and a limited use of performance information, performance management in Lithuania led to significant positive developments in the EU-pre accession phase. He concludes that sustained effort is needed if citizens are to benefit from performance management, but no major unintended negative effects resulting from performance 
management were documented. So it seems that overall performance management did achieve significant improvements. Similarly, evidence was found of concrete improvements in processes following performance management in local governments in Albania, Georgia and Hungary (Mark and Nayyar-Stone 2004). Insufficient policy making and management capacity hampered but did not cancel the merits of reform. Again, we see evidence of positive effects stemming from performance management with no major concerns about deteriorations in other areas.

\section{Evidence of positive impact of quality improvement schemes, agencification and benchmarking}

The Appendix includes examples of improvements resulting from quality improvement schemes and agencification in different countries, sectors and government levels. While success is uneven and dependent on methodological support and investment in human resources, quality models are on the rise in various countries in the region. Research in Slovenia, for example, documents experience of successful implementation leading to concrete results and the creation of smart practices (Kovač 2008; Kovač and Leskovšek 2009). One recommendation that proved effective was to combine various models - for instance balanced scorecard combined with common assessment framework. In this way the drawbacks of one scheme could be compensated by the advantages of the other scheme. While hindered by context in the form of developing structure and culture, Tõnnisson (2004) concludes by recommending quality models as a means to improve quality. Again, this suggests that adjustments need to be made to adapt quality models - to fit them to the local context - but this, however, does not imply that quality models should be renounced upon altogether (see also Jenei and Gulácsi 2004 and Reinholde 2004 for additional examples in Hungary and Latvia).

We identified a similar pattern concerning the effects of agencification and benchmarking. Various empirical research papers identify barriers but provide evidence of improvements and recommend solutions to address these barriers and sustain reform over a long period of time. Examples include central government agencies in Croatia where over-politicization, coordination problems, the lack of an institutionalized legal framework and administrative capacity hindered reform (Musa and Kopric 2011). Similar barriers were found in Slovakia and Lithuania. Nevertheless, overall agencification was assessed as an "important step forward" (Nemec, Mikusova Merickova and Vozarova 2011: 140 see also Nakrošis and Martinaitis 2011 for a detailed study of Lithuanian agencies). An evaluation of the impact of autonomous vocational schools in Lithuania found clear evidence on efficiency (although less clear evidence on quality) in autonomous schools compared to those which did not undergo the reform (Golubova 2011).

\section{Evidence of positive impact of public management and modernization reforms}

A number of studies in Estonia, Latvia, Lithuania and Romania have found evidence of a positive impact of public management and modernization reforms. These include multi- 
annual modernization plans (MMPs) and common assessment framework (CAF) which were positively perceived in the Romanian public sector. Findings indicate that processes and efficiency improved, and created the impetus for cultural change towards results-based public management (Profiroiu et al. 2006; Profiroiu et al. 2010). These findings need to be interpreted with caution due to social desirability bias, but perceptions of success vary across reform initiatives which may indicate that some effort was made to ensure objectivity. Importantly, the NPM-type measures were assessed more favorably than the other initiatives. Most respondents considered that multiannual modernization plans and the common assessment framework have either led to improvements or will lead to improvements in the future (Profiroiu et al. 2010). Similar conclusions were reached in Latvia and Lithuania where a World Bank study found that both countries had made considerable progress with strategic planning and policy management. If reforms continue, it is expected that progress will continue in the future (World Bank 2006). A survey of Estonian heads of local government revealed that NPM approaches were positively perceived in terms of efficiency and effectiveness (Tõnnisson 2006). Similarly to other studies, the author argues that possessing the capacity to implement reform can lead to fruitful developments in the future.

\section{CONCLUSIONS}

As the new democracies of Central and Eastern Europe embarked on their roads towards political and administrative modernization, NPM reforms instruments were often seen as a solution to poor processes, inefficiency and ineffective public services. Years later, NPM still draws much interest from academics and practitioners alike.

Whether NPM reforms have worked is no easy question. This review has revealed a balanced picture of the impact of NPM across Central and Eastern Europe and showed that NPM can

and has worked. Reforms have not always been successful, as many of the studies reviewed in this paper indicate. However, there is considerable evidence to argue that some of the central reform measures in NPM - such as performance management, quality improvement and the creation of agencies - have led to certain improvements in the organization or delivery of public services across the region.

A number of limitations to this study need to be acknowledged. First, as a study of NPM, it can shed little light on the comparative question of whether NPM or another competing approach (e.g. neo-Weberianism, New Public Governance) is the most promising reform strategy. Second, most of the studies were carried out at particular points in time, and do not benefit from much longitudinal extension. So it is possible that the picture we have found may improve or deteriorate in the medium or longer term. Third, we have been comparing studies which have employed different designs and methods, and which have started from a range of different theoretical assumptions. The methods used in the studies therefore did not allow statistical analysis and quantification of the size of effects. These may constitute meaningful and timely avenues for future research. There is hope that comparative data become increasingly available which could allow the adoption of other research strategies. Likewise, experimental designs, which have drawn much interest in recent years in political science and 
public administration, may well start to be used to document the impact of reforms in Central and Eastern Europe, as it has been the case elsewhere (for example James, 2011; Margetts, 2011; Propper et al. 2008). NPM has also grown in developing countries and it is important to also take stock of the evidence accumulated thus far in this part of the world. The experience in Central and Eastern Europe can be better used than that of developed countries in so far as developing countries share challenges and opportunities that better reflect the realities of CEE states. It was not the purpose of this article to identify what reform success or failure means what was the meaning of claiming that NPM instruments 'worked' - and for whom. For some stakeholders certain instruments may have well worked (service users or citizens, for instance) while for others they may have failed to do so (say, civil servants).

Nevertheless, the study reviewed considerable evidence of positive effects and developments following the use of NPM instruments. This has not been the case for only a particular NPM instrument or country. We found examples of improvements across the spectrum of NPM in different Central and Eastern European countries. Adequate levels of administrative capacity, a context that fits NPM ideas and sustained effort over a longer period of time can tip the scale for success.

These findings lead to a number of implications. First, contrary to previous work which dismissed NPM altogether, we suggest that policy makers in Central and Eastern Europe may do well to continue to consider the possibility of modernizing public service organization and provision by means of NPM practices. These, however, need to be carefully assessed and adapted to existing levels of administrative capacity and resources as well as to the broader political, administrative, financial and cultural context. Second, we suggest that claims that either see NPM as a generic solution to most public sector ills or those that dismiss NPM altogether are not consonant with the available evidence. None of the empirical studies reviewed in this article fits either of these more extreme judgments. The reality is more nuanced - it is very likely that NPM reforms will give rise to a host of intended and unintended consequences - some positive, others negative, some easy to control others more difficult to manage. Expectations therefore need to be reasonable. It is unlikely that the use of any NPM reform or instrument will immediately solve deep-seated and long-lasting public sector problems. This article casts a fresh look at the existing empirical literature on NPM across Central and Eastern and shows that while NPM instruments have not always worked, there are many examples showing evidence of short-term effects and long-term positive impact.

\section{ACKNOWLEDGEMENTS}

We would like to thank Trui Steen for helpful comments on an earlier draft and three anonymous Public Management Review referees.

This project has received funding from the European Union's Seventh Framework Programme for research, technological development and demonstration under grant agreement no 266887 (Project COCOPS). 


\section{REFERENCES}

Baba, A., Balogh, M., Dragoș, D., Marian, C., Pop, D., Renert, C. and Suciu, A.M. (2007) Impactul serviciilor deconcentrate ale ministerelor asupra politicilor publice locale (Impact of deconcentrated services of the ministries on local public policy), Bucharest: Soros Foundation Romania

Bouckaert, G., Nemec, J., Nakrošis, V., Hajnal, G. and Tõnnisson, K. eds (2008) Public Management Reforms in Central and Eastern Europe, Bratislava: NISPAcee Press

Boyne, G., A., Farrell, C., Law, J., Powell, M., and Walker, R., M. (2003) Evaluating Public Management Reforms, Buckingham: Open University Press

Bouckaert, G., Nakrošis, V. and Nemec, J. (2011) Public administration and management reforms in CEE: Main trajectories and results, NISPAcee Journal of Public Administration and Policy, IV(1) pp9-29

Caddy, J. and Vintar, M. (2002) Building better quality administration for the public: case studies from Central and Eastern Europe, Bratislava: NISPAcee Press

Drechsler, W. (2005) The Re-Emergence of "Weberian" Public Administration after the Fall of New Public Management: The Central and Eastern European Perspective, Halduskultuur 6 pp94-108.

Drechsler, W. (2009) The rise and demise of the New Public Management: Lessons and opportunities for South East Europe, Uprava VII(3) pp7-27

Drechsler, W. and Kattel, R. (2008) Towards the Neo-Weberian State? Perhaps, but certainly adieu NPM! NISPAcee Journal of Public Administration and Policy, 1(2) pp95-99

Dunleavy, P., Margetts, H., Bastow, S. and Tinkler, J. (2006) New Public Management is Dead - Long Live Digital-Era Governance, Journal of Public Administration Research and Theory, 16:3 pp467-494

Dunn, W. N., Staroňová, K. and Pushkarev, S. ed. (2006) Implementation: The Missing Link in Public Administration Reform in Central and Eastern Europe, Bratislava: NISPAcee Press

Golubova, E. (2011) The impact of greater autonomy on efficiency of work and quality of services in public service providers: a case of vocational education institutions, Annals of Public and Cooperative Economics 82(4) pp475-494

James, O. (2011) Performance measures and democracy: information effects on citizens in field and laboratory experiments, Journal of Public Administration Research and Theory 21(3), 399-418.

Järvalt, J. and Randma-Liiv, T. (2010) Public sector HRM: the case of no central human resource strategy, Baltic Journal of Management, 5:2 pp242-256. 
Jenei, G. and Gulácsi, L. (2004) 'Do Western quality models work in CEE countries? Some insights from the Hungarian Perspective' in E. Löffler and M. Vintar (eds) Improving the Quality of East and West European Public Services, Chippenham: Ashgate

Jenei, G. and Zupkó, G. (2001) Public sector performance in a new democratic state: the Hungarian case, International Review of Administrative Sciences, 67 pp77-98

Jenei, G., Kutib, É., Horváthc, Á., and Palotai, Z. (2005) Local governments, civil society organizations and private enterprises - partnerships in providing social services: the case of Eger, Hungary, Journal of Comparative Policy Analysis, 7:1 pp73-94.

Kovač, P. (2008) Integracija modela odličnosti EFQM in sistema uravnoteženih kazalnikov BSC v javni upravi (Integration of the EFQM Excellence model and the system of balanced scorecards in public administration), Uprava VI(1) pp57-80

Kovač, P. and Leskovšek, B. (2009) Innovativeness as part of quality and excellence development in the Slovenian public administration, Uprava VII(1) pp45-70

Lember, V. (2006) 'On the Importance of Ex Ante Analysis in Implementing Contracting Out: Lessons from the Estonian Emergency Medical Service’ in W. Dunn, K. Staranova, and S. Pushkarev (eds) Implementation: the Missing Link in Public Administration Reform in Central and Eastern Europe, Bratislava: NISPAcee

Linder, V (2011) Balancing between the career and position-based systems. Some aspects of recent developments in civil service legislation in Hungary, Acta Juridica Hungarica, 52:1 pp $64-72$

Mark, K. and Nayyar-Stone, R. (2004) 'Early experience with performance management in Hungary, Albania and Georgia: Assessing its potential for local service improvement' in E. Löffler and M. Vintar (eds) Improving the Quality of East and West European Public Services, Chippenham: Ashgate

Margetts, H. (2011) Experiments for public management research Public Management Review 13(2), 189-208.

Meyer-Sahling, J-H and Nakrošis, V. (2009) The Lithuanian Civil Service and Its Modernisation Guidelines. Vilnius: Civil Service Department of the Government of Lithuania.

Meyer-Sahling, J-H and Yesilkagit, K. (2011) Differential legacy effects: three propositions on the impact of administrative traditions on public administration reform in Europe East and West, Journal of European Public Policy, 18:2, pp 311-322.

Musa, A. and Kopric, I. (2011) What kind of agencification in Croatia? Trends and future directions, Transylvanian Review of Administrative Sciences, Special Issue, pp33-53

Nakrošis, V. (2008) 'Reforming Performance Management in Lithuania: Towards Resultsbased Government' in G.B. Peters (ed) Mixes, Matches and Mistakes: New Public 
Management in Russia and the Former Soviet Republics, pp53-116, Budapest: Open Society Institute

Nakrošis, V. and Martinaitis, Z. (2011) Lithuanian agencies and other public sector organizations: Organisation, autonomy, control and performance, Vilnius: Vilnius University National Audit Office of Estonia (2002) Utilization of Payroll Funds Allocated for the Payment of Performance Wages, Tallinn : National Audit Office

Nemec, J. (2007) Decentralization reforms and their relations to local democracy and efficiency: CEE lessons, Uprava $\mathrm{V}(3) \mathrm{pp} 7-40$

Nemec, J. (2008) 'Public Management Reforms in CEE: Lessons Learned', in Bouckaert, G., Nemec, J., Nakroŝis, V., Hajnal, G. and Tõnnisson, K. (eds) Public Management Reforms in Central and Eastern Europe, Bratislava: NISPAcee Press

Nemec, J. (2010) New Public Management and its implementation in CEE: What do we know and where do we go? NISPAcee Journal of Public Administration and Policy III(1) pp31-52.

Nemec, J. and Kolisnichenko, N. (2006) Market-based healthcare reforms in Central and Eastern Europe: lessons after ten years of change, International Review of Administrative Sciences 72(1) pp11-26

Nemec, J., Merickova, B. and Ochrana, F. (2008) Introducing benchmarking in the Czech Republic and Slovakia: Processes, problems and lessons, Public Management Review 10(5) pp673-684

Nemec, J., Merickova, B. and Sumpikova Fantova, M. (2011) Is the Estonian Municipal Benchmarking Really Better? The impacts of research methodology on research results, Public Management Review, 13(4) pp539-549

Nemec, J., Merickova, B. and Vitec, L. (2005) Contracting-out at local government level: Theory and selected evidence from the Czech and Slovak Republics, Public Management Review, 7(4) pp637-647

Nemec, J., Mikusova Merickova, B. and Vozarova, Z. (2011) Agencification in Slovakia: The current situation and lessons learned, Transylvanian Review of Administrative Sciences, Special Issue, pp140-159

Nemec, J. and de Vries, M. (2012) Public sector dynamics in Central and Eastern Europe, Bratislava: NISPAcee Press

NISPAcee Journal of Public Administration and Policy, V(2), 2012/2013, The Politics of Agency Governance 
Nõmm, K. and Randma-Liiv, T. (2012) Performance measurement and performance information in new democracies: A study of the Estonian central government, Public Management Review, 14(7) pp859-879

OECD (1995) Governance in transition: public management reforms in OECD countries. Paris: PUMA/OECD.

Osborne, D. \& Gaebler, T. (1992) Reinventing government: how the entrepreneurial spirit is transforming the public sector. New York, NY: Addison Wesley Publishing Company.

Osborne, S. P., Jenei, G. and Fabian, G. (2008) Whispering at the back door?: Local government - voluntary and community sector relationships in post-accession Hungary, Public Policy and Administration, 23:4 pp331-350

Peters, Guy, B. (2008) (Ed.) Mixes, Matches and Mistakes: New Public Management in Russia and the Former Soviet Republics, Budapest: Open Society Institute

Pollitt, C. (2004) 'Castles built on sand? Agencies in Latvia' in C. Pollitt and C. Talbot (eds) Unbundled Government: A critical analysis of the global trend to agencies, quangos and contractualisation, pp283-296, London: Routledge

Pollitt, C. and Bouckaert, G. (2011) Public Management Reform: A Comparative Analysis: New Public Management, Governance and the Neo-Weberian State $3_{2}^{\text {rd }}$ edition, Oxford: Oxford University Press

Pollitt, C. and Dan, S. (2011) 'The Impacts of the New Public Management in Europe: A Meta-analysis', Deliverable 1.1. COCOPS Project.

Pollitt, C. and Dan, S. (2013) Searching for impacts in performance-oriented management reform: A review of the European literature, Public Performance \& Management Review, 37(1) pp7-32

Profiroiu, M., Andrei, T., Dinca, D. and Carp, R. (2006) Reforma administraţiei publice în contextul integrării europene (Public administration reform in the context of European integration), Romanian European Institute, Impact study III, Bucharest

Profiroiu, A., Andrei, T., Nica, M., and Ștefănescu, E. D. (2010) Analysis of the national modernizers network for the support of the public administration reform from Romania, Transylvanian Review of Administrative Sciences 31E, pp114-132

Propper, C., Sutton, M., Whitnall, C. \& Windmeijer, F. (2008) Incentives and targets in hospital care: evidence from a natural experiment. Bath, CMPO Working Paper 9.

Randma-Liiv, T. (2005) Performance Management in Transitional Administration: Introduction of Pay-for-Performance in the Estonian Civil Service, Journal of Comparative Policy Analysis: Research and Practice, 7:1 pp95-115 
Randma-Liiv, T., Nakrošis, V. and Hajnal, G. (2011) Public sector organization in Central and Eastern Europe: From agencification to de-agencification, Transylvanian Review of Administrative Sciences, Special Issue, pp160-175

Reinholde, I. (2004) 'ISO 9001 by Decree': The Latvian approach to quality management in the public sector' in E. Löffler and M. Vintar (eds) Improving the Quality of East and West European Public Services, Chippenham: Ashgate

Sarapuu, K. (2011) Post-communist development of administrative structure in Estonia: from fragmentation to segmentation, Transylvanian Review of Administrative Sciences, Special Issue, pp 54-73.

Şandor, D. S and Tripon, C. R. (2008) Citizens' perceptions about public administration reforms in Romania, Transylvanian Review of Administrative Sciences 24E, pp111-122.

Tönnisson K. (2004) 'The effect of organizational structures and cultures on quality management in Estonian local authorities' in E. Löffler and M. Vintar (eds) Improving the Quality of East and West European Public Services, Chippenham: Ashgate

Tönnisson K. (2006) 'Why CEE countries, NPM principles and bad policy implementation could easily be fatal friends: The case of Estonian local governments" in W. Dunn, K. Staranova, and S. Pushkarev (eds) Implementation: the Missing Link in Public Administration Reform in Central and Eastern Europe, Bratislava: NISPAcee

Tõnnisson, K. and Wilson, J. (2007) Best value in transitional countries? Some evidence from Estonia, Public Management Review, 9(1) pp87-106

Van Thiel, S. (2011) Comparing agencification in Central Eastern European and Western European countries: Fundamentally alike in unimportant respects? Transylvanian Review of Administrative Sciences, Special Issue, pp15-32

Verheijen, T. and Dobrolyubova, Y. (2007) Performance management in the Baltic States and Russia: success against the odds? International Review of Administrative Sciences 73(2) pp205-215

World Bank (2006) Report on strategic planning and policy management in Lithuania and Latvia, Background Paper, Report number: 36930-GLB, Poverty reduction and economic management unit, Europe and Central Asia, World Bank 


\section{Appendix: The impact of NPM reforms in Central and Eastern Europe}

\begin{tabular}{|c|c|c|c|c|c|}
\hline Reference & $\begin{array}{l}\text { Organizational } \\
\text { setting }\end{array}$ & Country & Method & $\begin{array}{l}\text { Type of } \\
\text { impact }\end{array}$ & Explanation \\
\hline \multicolumn{6}{|c|}{ Performance management and measurement systems including performance-related pay $(P R P)$} \\
\hline $\begin{array}{l}\text { National Audit } \\
\text { Office of } \\
\text { Estonia, } 2002\end{array}$ & $\begin{array}{l}\text { Central and } \\
\text { regional } \\
\text { government and } \\
\text { agencies }\end{array}$ & Estonia & $\begin{array}{l}\text {-Multiple case studies: } 4 \\
\text { ministries and central } \\
\text { agencies } \\
\text {-Interviews with } \\
\text { stakeholders } \\
\text {-Analysis of official } \\
\text { documents }\end{array}$ & Type II & $\begin{array}{l}\text {-Insufficient capacity and technical support to set measurable goals } \\
\text {-Performance-related pay not linked with results and government objectives due } \\
\text { to unclear definition of results and an almost general payment of PRP regardless } \\
\text { of actual performance } \\
\text {-Necessary information was not systematically gathered and assessed }\end{array}$ \\
\hline Linder, 2011 & $\begin{array}{l}\text { Human resource } \\
\text { management, civil } \\
\text { service }\end{array}$ & Hungary & $\begin{array}{l}\text { Critical analytical overview } \\
\text { with limited empirical } \\
\text { evidence }\end{array}$ & Type IV & $\begin{array}{l}\text {-Staff motivation improved initially but then deteriorated } \\
\text {-Frequent and in some cases incoherent amendments in civil service legislation } \\
\text { leading to tension between classical career-based and performance-based logics } \\
\text {-Lack of objectivity in measuring performance } \\
\text {-Limited capacity } \\
\text {-Frequent changes have led to uncertainty and lack of trust in civil service }\end{array}$ \\
\hline $\begin{array}{l}\text { Randma-Liiv, } \\
2005\end{array}$ & $\begin{array}{l}\text { Central and } \\
\text { regional } \\
\text { government and } \\
\text { agencies }\end{array}$ & Estonia & $\begin{array}{l}\text {-Multiple case studies: } 4 \\
\text { ministries and central } \\
\text { agencies } \\
\text {-Interviews with civil } \\
\text { servants } \\
\text {-Analysis of official } \\
\text { documents }\end{array}$ & Type II & $\begin{array}{l}\text {-Insufficient capacity and technical support to set measurable goals } \\
\text {-Inadequate integration of action plans into broader government goals, unclear } \\
\text { definition of results and an almost general payment of PRP regardless of actual } \\
\text { performance } \\
\text {-Necessary information was not systematically gathered and assessed, no } \\
\text { systematic monitoring } \\
\text {-Scheme introduced under time constraints } \\
\text {-Poor analysis of previous and international experience and research }\end{array}$ \\
\hline $\begin{array}{l}\text { Nõmm and } \\
\text { Randma-Liiv, } \\
2012\end{array}$ & Central government & Estonia & Official documentation & Type II & $\begin{array}{l}\text { - Instability, poor strategic planning and policy analysis } \\
\text { - Implementation gap } \\
\text { - Uncritical transfer of Western performance management practices }\end{array}$ \\
\hline Verheijen and & Central government & $\begin{array}{l}\text { Latvia, } \\
\text { Lithuania }\end{array}$ & Analytical overview & Type VI & $\begin{array}{l}\text {-Incremental approach to reform can facilitate implementation, overall assessed } \\
\text { positively }\end{array}$ \\
\hline
\end{tabular}




\begin{tabular}{|c|c|c|c|c|c|}
\hline $\begin{array}{l}\text { Dobrolyubova, } \\
2007\end{array}$ & & and Russia & & & $\begin{array}{l}\text {-Success is facilitated by adaptation of reform efforts to existing capacity levels } \\
\text {-Stumbling blocks include low capacity levels and weak personnel systems as } \\
\text { well as the need to implement performance systems at micro level in addition to } \\
\text { macro level } \\
\text {-Need to foster personal responsibility for results which can be facilitated by the } \\
\text { definition of individual goals and targets }\end{array}$ \\
\hline $\begin{array}{c}\text { Meyer-Sahling } \\
\text { and Nakrošis, } \\
2009\end{array}$ & Civil service reform & Lithuania & $\begin{array}{l}\text {-Survey with civil servants, } \\
188 \text { full responses and } 226 \\
\text { partial responses } \\
\text {-Survey of Lithuanian public } \\
\text { administration experts, } 9 \\
\text { responses } \\
-11 \text { interviews with experts } \\
\text { and civil servants }\end{array}$ & Type VI & $\begin{array}{l}\text { Certain NPM and managerial ideas are recommended such as a move towards } \\
\text { position-based system, performance-related pay and competence management }\end{array}$ \\
\hline $\begin{array}{c}\text { Mark and } \\
\text { Nayyar-Stone, } \\
2004\end{array}$ & Local government & $\begin{array}{l}\text { Albania, } \\
\text { Georgia } \\
\text { and } \\
\text { Hungary }\end{array}$ & Mini case studies & Type VI & $\begin{array}{l}\text {-Concrete improvements in processes in the selected cases } \\
\text {-Obstacles such as insufficient capacity in policy making and management } \\
\text { hamper the effects of reform, but they do not cancel out the merits and positive } \\
\text { improvements associated with performance management }\end{array}$ \\
\hline Nakrošis, 2008 & Central government & Lithuania & Mixed methods & Type V & $\begin{array}{l}\text {-Significant positive developments in the EU pre-accession period } \\
\text {-Certain gaps remain due to insufficient resources and limited use of } \\
\text { performance information } \\
\text {-Need for sustained effort if NPM is to lead to positive effects to the citizens } \\
\text {-No major documented unintended effects resulting from performance } \\
\text { management }\end{array}$ \\
\hline \multicolumn{6}{|c|}{ Quality improvement techniques } \\
\hline Kovač, 2008 & $\begin{array}{l}\text { Local government } \\
\text { and other public } \\
\text { organizations }\end{array}$ & Slovenia & Multiple case studies & Type V & $\begin{array}{l}\text {-Positive examples of successful implementation exist leading to concrete } \\
\text { positive effects in these cases } \\
\text {-Focus on best practices } \\
\text {-The drawbacks of one tool alone can be minimized by combining them, for } \\
\text { instance balanced scorecard (BSC) with quality models (CAF and EFQM) } \\
\text { which is said to be optimal in case of Slovenian public organizations }\end{array}$ \\
\hline
\end{tabular}




\begin{tabular}{|c|c|c|c|c|c|}
\hline $\begin{array}{l}\text { Kovač and } \\
\text { Leskovšek, } \\
2009\end{array}$ & $\begin{array}{l}\text { Central, local } \\
\text { government and } \\
\text { affiliated agencies } \\
\text { and public entities } \\
\text { in different sectors }\end{array}$ & Slovenia & $\begin{array}{l}\text {-Survey of public sector } \\
\text { organizations } \\
\text {-Sample size: } 400 \\
\text { organizations } \\
\text {-Response rate: } 33 \%\end{array}$ & Type V & $\begin{array}{l}\text {-Quality improvement tools are on the rise but they are not yet used } \\
\text { systematically by all public sector organizations } \\
\text {-Greater innovation and better results are positively related to investment in } \\
\text { human resources } \\
\text {-Positive examples of successful implementation exist but success is uneven } \\
\text { across the different organizations surveyed } \\
\text {-Impacts are not assessed due to lack of methodological support } \\
\text {-Need for a consistent policy of quality management }\end{array}$ \\
\hline $\begin{array}{l}\text { Tõnnisson, } \\
2004\end{array}$ & Local government & Estonia & $\begin{array}{l}-73 \text { interviews with public } \\
\text { officials } \\
-156 \text { interviews with citizens } \\
\text { and other stakeholders } \\
\text {-Direct observation }\end{array}$ & Type V & $\begin{array}{l}\text { Despite issues with organizational structure and culture, the author recommends } \\
\text { quality schemes and suggests solutions to overcome obstacles }\end{array}$ \\
\hline $\begin{array}{l}\text { Jenei and } \\
\text { Gulácsi, } 2004\end{array}$ & Various sectors & Hungary & $\begin{array}{l}\text {-Analytical overview } \\
\text {-Small number of interviews }\end{array}$ & Type V & $\begin{array}{l}\text { Well-developed Weberian system is a prerequisite for quality schemes to work } \\
\text { alongside locally-developed systems and a clear understanding of the functions } \\
\text { of quality models }\end{array}$ \\
\hline $\begin{array}{l}\text { Reinholde, } \\
2004\end{array}$ & $\begin{array}{l}\text { Central agencies } \\
\quad \text { and local } \\
\text { government, } \\
\text { various sectors }\end{array}$ & Latvia & $\begin{array}{l}\text {-Survey of } 6 \text { central and } \\
\text { local public organizations }\end{array}$ & Type V & $\begin{array}{l}\text {-Top-down approach to implementation, which facilitated a formal rather than } \\
\text { results-based approach to quality } \\
\text {-Limited financial resources seen as major barrier }\end{array}$ \\
\hline \multicolumn{6}{|c|}{ Contracting out and public-private partnerships (PPPs) } \\
\hline $\begin{array}{l}\text { Osborne, Jenei } \\
\text { and Fabian, } \\
2008\end{array}$ & Local government & Hungary & $\begin{array}{l}\text {-Single case study } \\
\text {-Interviews with different } \\
\text { stakeholders } \\
\text {-Analysis of official } \\
\text { documents }\end{array}$ & Type V & $\begin{array}{l}\text {-Role of civil society in transparent co-production and policy making is still } \\
\text { limited, but the role of local actors in influencing policy making is improving } \\
\text {-Top-down centralism } \\
\text {-Presence of informal networks and channels that affect transparency and } \\
\text { accountability } \\
\text {-Limited financial resources that may alter voluntary organizations' mission by } \\
\text { creating dependency on state funding }\end{array}$ \\
\hline $\begin{array}{l}\text { Jenei et al. } \\
2005\end{array}$ & Local government & Hungary & $\begin{array}{c}\text { Single case study (one } \\
\text { municipality but various } \\
\text { non-governmental partners) }\end{array}$ & Type V & $\begin{array}{l}\text {-Overall public-private partnerships (PPPs) have intensified and become more } \\
\text { professional } \\
\text {-Policy coordination, service integration and social policy legitimacy improved }\end{array}$ \\
\hline
\end{tabular}




\begin{tabular}{|c|c|c|c|c|c|}
\hline & & & & & $\begin{array}{l}\text {-A rich history of PPPs facilitated further development of this practice } \\
\text {-Lack of clarity of goals and imbalanced power relations may jeopardize } \\
\text { successful PPPs } \\
\text {-Growing mutual understanding of needs and opportunities facilitated PPPs }\end{array}$ \\
\hline Lember, 2006 & $\begin{array}{l}\text { Emergency medical } \\
\text { service }\end{array}$ & Estonia & $\begin{array}{l}\text {-Single case study } \\
\text {-Analysis of official } \\
\text { documents and a limited } \\
\text { number of interviews }\end{array}$ & Type II & $\begin{array}{l}\text {-Salient implementation problems due to lack of ex-ante policy analysis } \\
\text {-Political, legal and administrative-economic factors: lack of capacity and } \\
\text { resources to manage contracts, unclear policy, insufficient analysis in the design } \\
\text { stage }\end{array}$ \\
\hline $\begin{array}{c}\text { Nemec, } \\
\text { Merickova and } \\
\text { Vitec, } 2005\end{array}$ & Local government & $\begin{array}{l}\text { Czech } \\
\text { Republic } \\
\text { and } \\
\text { Slovakia }\end{array}$ & Administrative data & Type II & $\begin{array}{l}\text { - Unsystematic decision making of the delivery model } \\
\text { - Inadequate quality of contract design and contract management }\end{array}$ \\
\hline \multicolumn{6}{|c|}{ Decentralization } \\
\hline $\begin{array}{c}\text { Järvalt and } \\
\text { Randma-Liiv, } \\
2010\end{array}$ & Central government & Estonia & $\begin{array}{l}\text {-Survey of managers and } \\
\text { senior civil servants } \\
-80 \text { responses, response rate } \\
62.5 \% \text { (HR managers) and } \\
58 \text { or } 74 \% \text { response rate } \\
\text { (senior civil servants) }\end{array}$ & Type IV & $\begin{array}{l}\text {-Decentralized HRM strategy was not systematic } \\
\text { but it facilitated other major public sector reform } \\
\text {-Lack of a central human resource strategy } \\
\text {-Frequent turnover of governments and fragmentation in the public sector } \\
\text {-Insufficient coordination } \\
\text {-Afforded the flexibility to implement reforms at the organizational level }\end{array}$ \\
\hline $\begin{array}{l}\text { Baba et al. } \\
\quad 2007\end{array}$ & Local government & Romania & $\begin{array}{l}-7 \text { case studies } \\
\text {-Interviews, press coverage } \\
\text { and analysis of legislation }\end{array}$ & Type III & $\begin{array}{l}\text {-Inadequate use of decentralization and deconcentration reforms leading to } \\
\text { duplication of tasks } \\
\text {-Administrative bottlenecks, double subordination and redundancies } \\
\text {-Lack of cohesion and overall poor coordination and control mechanisms due to } \\
\text { double subordination } \\
\text {-Fragmentation of local policy making, implementation and evaluation }\end{array}$ \\
\hline \multicolumn{6}{|c|}{ Agencification } \\
\hline Musa and & Central government & Croatia & Analytical overview & Type V & -Over-politicization and inadequate coordination \\
\hline
\end{tabular}




\begin{tabular}{|c|c|c|c|c|c|}
\hline Kopric, 2011 & $\begin{array}{l}\text { agencies, various } \\
\text { sectors }\end{array}$ & & & & $\begin{array}{l}\text {-Need to institutionalize agencies through a legal framework } \\
\text {-Need to improve civil service professionalism and capacity }\end{array}$ \\
\hline $\begin{array}{l}\text { Nemec, } \\
\text { Mikusova } \\
\text { Merickova and } \\
\text { Vozarova, } \\
2011\end{array}$ & $\begin{array}{l}\text { Central and local } \\
\text { agencies, various } \\
\text { sectors }\end{array}$ & Slovakia & Case studies & Type V & $\begin{array}{l}\text {-Overall assessed as an important step forward } \\
\text {-Problems include the lack of a systematic conceptual framework and } \\
\text { implementation problems } \\
\text {-Democratization, public awareness, participation and control seen as possible } \\
\text { remedies }\end{array}$ \\
\hline $\begin{array}{l}\text { Nakrošis and } \\
\text { Martinaitis, } \\
2011\end{array}$ & $\begin{array}{l}\text { Central government } \\
\text { agencies, various } \\
\text { sectors }\end{array}$ & Lithuania & $\begin{array}{l}\text {-Survey of agencies, } 37 \% \\
\text { response rate } \\
\text {-Detailed case studies of } \\
\text { specific agencies } \\
\text {-33 interviews }\end{array}$ & Type V & The Lithuanian context is seen as key in the development of agencies over time \\
\hline $\begin{array}{l}\text { Golubova, } \\
2011\end{array}$ & $\begin{array}{l}\text { Vocational } \\
\text { education }\end{array}$ & Lithuania & $\begin{array}{l}\text {-Quantitative/statistical data } \\
-27 \text { stakeholder interviews }\end{array}$ & Type VI & $\begin{array}{l}\text { Positive effects on efficiency of autonomous schools, less clear effects on } \\
\text { quality }\end{array}$ \\
\hline \multicolumn{6}{|c|}{ Benchmarking } \\
\hline $\begin{array}{l}\text { Nemec, } \\
\text { Merickova and } \\
\text { Ochrana, } 2008\end{array}$ & $\begin{array}{l}\text { Local government, } \\
\text { various sectors }\end{array}$ & $\begin{array}{l}\text { Czech } \\
\text { Republic } \\
\text { and } \\
\text { Slovakia }\end{array}$ & Analytical overview & Type V & $\begin{array}{l}\text {-Lack of accountability for performance is a main barrier } \\
\text {-Rent-seeking behavior of elected officials } \\
\text {-Territorial fragmentation (high number of different municipalities) affecting } \\
\text { capacity }\end{array}$ \\
\hline $\begin{array}{l}\text { Nemec, } \\
\text { Merickova and } \\
\text { Sumpikova } \\
\text { Fantova, } 2011\end{array}$ & Local government & $\begin{array}{l}\text { Czech } \\
\text { Republic, } \\
\text { Estonia } \\
\text { and } \\
\text { Slovakia }\end{array}$ & $\begin{array}{l}\text { Sample of local government } \\
\text { representatives }\end{array}$ & Type V & $\begin{array}{l}\text {-Differences in methodology partly explain the relative success of } \\
\text { benchmarking in Estonia compared to Czech Republic and Slovakia } \\
\text {-Success factors in Estonia include lower levels of corruption, greater } \\
\text { accountability, selection process of external contractors and less territorial } \\
\text { fragmentation associated with greater capacity }\end{array}$ \\
\hline $\begin{array}{l}\text { Tõnnisson and } \\
\text { Wilson, } 2007\end{array}$ & Local government & Estonia & $\begin{array}{l}\text { Survey of heads of local } \\
\text { governments, } 231 \text { responses, } \\
96 \% \text { response rate }\end{array}$ & Type V & $\begin{array}{l}\text {-No definite conclusions on impact but overall the paper argues that Estonia has } \\
\text { pursued a NPM program of reforms } \\
\text {-Certain possible contradictions and trade-offs are discussed }\end{array}$ \\
\hline
\end{tabular}




\begin{tabular}{|c|c|c|c|c|c|}
\hline $\begin{array}{c}\text { Jenei and } \\
\text { Zupkó, } 2001\end{array}$ & $\begin{array}{l}\text { Public sector more } \\
\text { generally }\end{array}$ & Hungary & $\begin{array}{l}\text {-Analytical overview } \\
\text {-Use of existing public } \\
\text { opinion survey data }\end{array}$ & Type IV & $\begin{array}{l}\text {-Move towards customer and performance orientation, but no significant } \\
\text { cultural shift } \\
\text {-Decreasing levels of trust over time with a greater loss for politicians } \\
\text {-Market elements during communism facilitated the development of market } \\
\text { principles after communism }\end{array}$ \\
\hline $\begin{array}{l}\text { Profiroiu et al. } \\
\quad 2006\end{array}$ & $\begin{array}{l}\text { Public sector more } \\
\text { generally }\end{array}$ & Romania & $\begin{array}{l}\text { Large scale representative } \\
\text { survey measuring } \\
\text { perceptions of local mayors } \\
\text { and national network of } \\
\text { "modernizers" }\end{array}$ & Type V & $\begin{array}{l}\text {-Improved processes following multiannual modernization plans (MMPs) } \\
\text {-Improved efficiency and a perception of modernization } \\
\text {-Improved transparency in HR processes but no documented effect on } \\
\text { corruption } \\
\text {-Half of the sample was in favor of reforms but mentioned that a special fund } \\
\text { would have strengthened the reform efforts } \\
\text {-Poor implementation capacity creates a significant gap between legislation and } \\
\text { practice, affecting reform on a larger scale }\end{array}$ \\
\hline $\begin{array}{l}\text { Profiroiu et al. } \\
2010\end{array}$ & $\begin{array}{l}\text { Public sector more } \\
\text { generally }\end{array}$ & Romania & $\begin{array}{l}\text { Survey of the national } \\
\text { network of modernizers }\end{array}$ & Type V & $\begin{array}{l}\text {-Most respondents consider that the multiannual modernization plans (MMPs) } \\
\text { and common assessment framework (CAF) have either led to improvements or } \\
\text { will lead to improvements in the future } \\
\text {-Other elements assessed as having mostly "moderate" to "pretty good" } \\
\text { contribution }\end{array}$ \\
\hline $\begin{array}{l}\text { Șandor and } \\
\text { Tripon, } 2008\end{array}$ & $\begin{array}{l}\text { Public sector more } \\
\text { generally }\end{array}$ & Romania & $\begin{array}{l}\text {-National survey measuring } \\
\text { perceptions of citizens } \\
\text {-National survey of local } \\
\text { civil servants }\end{array}$ & Type III & $\begin{array}{l}\text {-The overall context hindered change on the ground } \\
\text {-Civil servants are perceived by the general public as resistant to change } \\
\text {-Politicization is perceived to affect implementation of reform and the quality } \\
\text { and professionalism of public services } \\
\text {-Lack of coherence and continuity of reform efforts as perceived by citizens } \\
\text {-Excessive legalism and complicated legal framework impeded implementation }\end{array}$ \\
\hline $\begin{array}{l}\text { World Bank, } \\
2006\end{array}$ & Central government & $\begin{array}{l}\text { Latvia and } \\
\text { Lithuania }\end{array}$ & $\begin{array}{l}\text { Interviews designed to } \\
\text { assess the state of strategic } \\
\text { planning and policy } \\
\text { management }\end{array}$ & Type V & $\begin{array}{l}\text {-Both countries have made significant progress with strategic planning and } \\
\text { policy management } \\
\text {-If reforms continue it is expected that further progress will be made } \\
\text {-Need for further improvement in ensuring effective control mechanisms and } \\
\text { monitoring along the entire implementation cycle } \\
\text {-Need to develop effective decision-making and management across the public } \\
\text { sector }\end{array}$ \\
\hline
\end{tabular}




\begin{tabular}{|c|c|c|c|c|l|}
\hline $\begin{array}{c}\text { Tönnisson, } \\
2006\end{array}$ & Local government & Estonia & $\begin{array}{c}\text { Survey of all } 241 \text { heads of } \\
\text { local government } \\
96 \% \text { response rate }\end{array}$ & Type V & $\begin{array}{l}\text {-NPM approaches perceived as positive in terms of efficiency and effectiveness } \\
\text {-Implementation gap affected impact, but so long as implementation capacity } \\
\text { exists, NPM can lead to positive developments }\end{array}$ \\
\hline
\end{tabular}

